\title{
Formulation and Evaluation of Lansoprazole Loaded Nanosponges
}

\author{
Lasoprazol Yüklü Nanosüngerlerin Formülasyonu ve \\ Değerlendirilmesi
}

\author{
Subhash Chandra Bose PENJURI ${ }^{*}$, Nagaraju RAVOURU², Saritha DAMINENI ${ }^{3}$, Sailakshmi BNS², Srikanth Reddy POREDDY1 \\ 1Department of Pharmaceutics, MNR College of Pharmacy, Sangareddy, Telangana, INDIA \\ 2Sri Padmavathi Mahila Visvavidyalayam (Women's University), Institute of Pharmaceutical Technology,Tirupati, Andhra Pradesh, INDIA \\ 3Department of Pharmaceutics, Sultan-ul-Uloom College of Pharmacy, Hyderabad, Telangana, INDIA
}

\begin{abstract}
Lansoprazole is proton pump inhibitor which extensively degraded in acidic $\mathrm{pH}$ conditions. Lansoprazole loaded nanosponges were prepared by Emulsion solvent diffusion method using ethylcellulose, PVA and pluronic F-68 and dichloromethane as a solvent. The prepared nanosponges were evaluated for percentage yield, incorporation efficiency, particle size, drug polymer compatibility, scanning electron microscopy and invitro drug release. SEM studies confirmed their porous structure with number of nanochannels. The FTIR spectra showed stable character of lansoprazole in mixture of polymers and revealed the absence of drug polymer interactions. DSC study revealed that drug was involved in complexation with nanosponges. The average particle size of lansoprazole nanoparticles was found to be in the range of $83.4 \mathrm{~nm}$ to $190.69 \mathrm{~nm}$. The negative zeta potential values were attained to ensure a good stability of nanosponges. The drug release from nanosponges was found to extended upto $12 \mathrm{~h}$. The optimized nanosponges were formulated in to enteric coated tablet and evaluated for weight variation, hardness, friability and dissolution studies. In-vitro release of drug from enteric coated tablet follows zero order and showed controlled release behavior for a period of $24 \mathrm{~h}$. The data obtained in this study suggests that nanosponges of lansoprazole are promising for controlled drug delivery, which can reduce dosing frequency.
\end{abstract}

Key words: Lansoprazole, Ethylcellulose, Pluronic F-68, Zero order, Nanosponges, Fickian release

\section{ÖZ}

Lansoprazol asidik pH koșullarında yoğun șekilde bozulan proton pompası inhibitörüdür. Lansoprazol yüklü nanosüngerler etilselüloz, PVA ve pluronic F68 ve solvan olarak da diklorometan kullanılarak emülsiyon çözücü difüzyon metodu ile hazırlandı. Hazırlanan nanosüngerler yüzde verim, yükleme etkinliği, partikül büyüklüğü, etkin madde polimer geçimliliği, taramalı elektron mikroskobu ve in vitro ekin madde salımı açısından değerlendirildi. SEM çalışmaları çok sayıda nanokanallar ile poröz yapılarını doğruladı. FTIR spektrumu polimer karışımı içinde lansoprazolün stabilitesini ve etkin madde polimer etkileşimi olmadığını gösterdi. DSC çalışması etkin maddenin nanosüngerle kompleks halinde olduğu ortaya çıkardı. Lansoprazol nanopartiküllerin ortalama partikül büyüklüğü 83.4 nm ile 190.69 nm aralı̆ında bulundu. Negatif zeta potansiyel değerlerine ulaşılması nanosüngerlerin iyi stabilite göstermelerini sağladı. Etkin maddenin nanosüngerlerden salımının 12 saate kadar uzatıldığı bulundu. Optimize edilmiş nanosüngerler enterik kaplı tabletler halinde formüle edildi ve ağırlık sapması, sertlik, friabilite ve çözünme çalışmaları değerlendirildi. Enterik kaplı tabletlerden etkin maddenin in vitro salımı sıfır dereceye uyumlu ve 24 saatlik periyotda kontrollü salım davranıșı gösterdi. Bu çalıșmadan elde edilen veriler gösterdi ki lansoprazol nanosüngerleri doz sıklığını azaltabilecek kontrollü salım için gelecek vaad etmektedir.

Anahtar kelimeler: Lansoprazol, Etilselüloz, Pluronic F68, Sıfır derece, Nanosünger, Fick salımı

\section{INTRODUCTION}

The drug delivery technology has certainly a new interest for drugs by providing them new life through their therapeutic targets. Nowadays, targeting drug delivery is the major problem which is being faced by the researchers. Target oriented drug administration with improvements in therapeutic efficacy, reduction in side effects and optimized dosing regimen, shall be the leading trends in the area of therapeutics. Targeted drug delivery implies for selective and effective localization of pharmacologically active moiety at pre identified target in therapeutic concentration, while restricting its access to non-target normal cellular linings and thus minimizing toxic effects and maximizing therapeutic index of the drug (1). 
Nanosponges have emerged as one of the most promising fields of science because of their perceived application in controlled drug delivery. Nanosponge delivery system can precisely control the release rates or target drugs to a specific body site and have an enormous impact on the health care system. This nanosized delivery system has definite advantages for the purpose of drug delivery because of its high stability, high carrier capacity and feasibility of incorporation of both hydrophilic and hydrophobic substances. The application of nanosponges for targeted and localized delivery of therapeutic agents is the driving force for the research in this area (2).

The sponge acts as a three-dimensional network or scaffold. The backbone is long-length polyester. It is mixed in solution with cross-linkers to form the polymer. The net effect is to form spherically shaped particles filled with cavities where drug molecules can be stored. The polyester is biodegradable, so it breaks down gradually in the body. As it breaks down, it releases its drug payload in a predictable fashion. The nanosponges can be synthesized to be specific size and to release drugs over time by varying proportions of crosslinker to polymer. The main limitation of nanosponges is their ability to include only small molecules (3).

Nanosponges are solid in nature and are small particles with porous surface can be formulated as oral, parenteral, topical or inhalational dosage forms. For oral administration, these may be dispersed in a matrix of excipients, diluents, lubricants and anti caking agents which is suitable for the preparation of tablets or capsules and the major benefits of these capsules or tablets are reduction of total dose, retention of dosage form, reduction in toxicity and improving patient compliance by prolonged release $(3,4)$. For parenteral administration, these can be simply mixed with sterile water, saline or other aqueous solutions (4). For topical administration, they can be effectively incorporated into topical hydrogel (5).

Lansoprazole is a proton pump inhibitor commonly used in the treatment of gastric ulcer, gastro oesophageal reflux disease (GERD), duodenal ulcer, ulcers associated with usage of Nonsteroidal anti-inflammatory drug (NSAID) and long term management Zollinger-Ellison syndrome (6). Lansoprazole is primarily metabolized by liver. Hence it is a need to reduce the dose to the hepatic failure patients. But reduction of dose in conventional dosage systems may not show sufficient pharmacological effect (7). Regular usage of lansoprazole causes various adverse effects like abdominal pain, diarrhoea, skin rashes, thrombocytopenia, impotence etc. So, controlled delivery of lansoprazole at optimal concentration may be required (8). Oral route is preferable than other routes with respect to safety, comfort and reliability. Hence controlled delivery of lansoprazole by oral route is ideal. Controlled release of lansoprazole will reduce the frequency of dosing and dose size and may increase patient convenience $(7,8)$. More over lansoprazole is highly acid labile and represents many formulation challenges to protect it from acidic environment of the stomach (9). So the aim of the present investigation was to formulate enteric coated tablets of lansoprazole nanosponges to protect it from acidic environment and deliver at controlled rate to its absorptive site so that its oral bioavailability can be enhanced $(8,9)$.

\section{MATERIAL AND METHOD}

Lansoprazole was gift sample from Dr. Reddy's Labs limited, Hyderabad. Ethyl Cellulose, Polyvinyl Alcohol and Pluronic F68 were purchased from Qualigens Fine chemicals, New Delhi. All other ingredients used were analytical grade.

\section{Methodology}

\section{Preparation of lansoprazole nanosponges $(5,10)$}

Lansoprazole nanosponges were prepared by different proportions of ethyl cellulose, polyvinyl alcohol and Pluronic F68 by emulsion solvent diffusion technique. The disperse phase consisting of $100 \mathrm{mg}$ lansoprazole and specified quantity of ethylcellulose (Table 1) dissolved in $30 \mathrm{~mL}$ of dichloromethane was slowly added to a definite amount of PVA in $100 \mathrm{~mL}$ of aqueous continuous phase. The mixture was stirred at $1000 \mathrm{rpm}$ on a magnetic stirrer for two hours. The formed lansoprazole nanosponges were collected by vacuum filtration and dried in an oven at $40^{\circ} \mathrm{C}$ for $24 \mathrm{~h}$.

\section{Percentage yield}

The lansoprazole nanosponges obtained after drying was weighed. Percentage yield value was calculated as follows (11): $\%$ yield $=$ Weight of nanosponges $\times 100 /$ Total solids weight

\section{Entrapment efficiency (11)}

UV spectrophotometric method was used to estimate entrapment efficiency of lansoprazole nanosponges. A calibration curve was plotted for lansoprazole in methanolic $\mathrm{HCl}$ in the range of $3-18 \mu \mathrm{g} / \mathrm{mL}$ (Beer's Lambert's range) at $293 \mathrm{~nm}$. A good linear relationship was observed between the concentration of lansoprazole and its absorbance $\left(r^{2}=0.9993\right.$, $m=0.0469, n=3$ ). $100 \mathrm{mg}$ of lansoprazole nanosponges of each batch were selected, powdered in a mortar and placed in $100 \mathrm{~mL}$ of methanolic $\mathrm{HCl}$. Lansoprazole was extracted by centrifuging at $1000 \mathrm{rpm}$ for $30 \mathrm{~min}$, filtered and analyzed concentration from calibration curve data after necessary dilution. Percentage entrapment was calculated as follows:

$\%$ Entrapment efficiency $=$ Actual drug content in the nanospongex100/Theoritical drug content

\section{Particle size measurement $(5,11)$}

The average particle size of lansoprazole nanosponges were determined by photon correlation spectroscopy (PCS) using a Nano ZS-90 (Malvern Instruments limited, UK) at a fixed angle at $25^{\circ}$. Sample was diluted 10 times with distilled water and then it was analyzed for particle size. 


\section{Zeta potential $(5,11)$}

The zeta potential was measured for the determination of the movement velocity of the particles in an electric field and the particle charge. In the present work, the nanosponges was diluted 10 times with distilled water and analyzed by Zetasizer using Laser Doppler Micro electrophoresis (Zetasizer nano ZS, Malvern instruments Ltd., UK).

\begin{tabular}{llllllll}
\hline \multicolumn{7}{l}{ Table 1. Composition of lansoprazole nanosponges } \\
& F1 & F2 & F3 & F4 & F5 & F6 \\
\hline Lansoprazole (mg) & 100 & 100 & 100 & 100 & 100 & 100 \\
\hline Polyvinyl alcohol (mg) & 600 & 800 & 900 & 1000 & 1100 & 1200 \\
\hline Ethyl cellulose (mg) & 400 & 600 & 800 & 1000 & 800 & 600 \\
\hline Pluronic F68 (mg) & 200 & 200 & 200 & 200 & 200 & 200 \\
\hline Dichloromethane (mL) & 30 & 30 & 30 & 30 & 30 & 30 \\
\hline Distilled water (mL) & 100 & 100 & 100 & 100 & 100 & 100 \\
\hline
\end{tabular}

\section{Table 2. Formulation of lansoprazole tablets}

\begin{tabular}{|c|c|c|c|c|}
\hline \multicolumn{3}{|c|}{ Ingredient } & \multicolumn{2}{|c|}{$\begin{array}{l}\text { Quantity } \\
\text { (mg) }\end{array}$} \\
\hline \multicolumn{3}{|c|}{ Nanosponges (F2) } & \multicolumn{2}{|c|}{$\begin{array}{l}35 \text { (equivalent to } \\
30 \mathrm{mg} \text { of lansoprazole) }\end{array}$} \\
\hline \multicolumn{3}{|c|}{ Microcrystalline cellulose } & \multicolumn{2}{|c|}{60} \\
\hline \multicolumn{3}{|c|}{ Magnesium stearate } & \multicolumn{2}{|c|}{5} \\
\hline & $\begin{array}{l}\text { Percentage } \\
\text { Yield }\end{array}$ & $\begin{array}{l}\text { Entrapment } \\
\text { efficiency }\end{array}$ & $\begin{array}{l}\text { Particle size } \\
(\mathrm{nm})\end{array}$ & $\begin{array}{l}\text { Zeta Potential } \\
(\mathrm{mV})\end{array}$ \\
\hline $\mathrm{F} 1$ & $38.35 \pm 1.27$ & $50.71 \pm 0.73$ & 190.69 & -4.9 \\
\hline F2 & $59.57 \pm 1.09$ & $86.93 \pm 0.65$ & 83.4 & -5.2 \\
\hline F3 & $34.68 \pm 1.17$ & $79.57 \pm 1.01$ & 103.26 & -5.6 \\
\hline F4 & $28.24 \pm 0.97$ & $78.04 \pm 1.62$ & 114.91 & -6.1 \\
\hline F5 & $33.31 \pm 2.1$ & $70.31 \pm 0.94$ & 135.33 & -5.3 \\
\hline F6 & $24.8 \pm 1.73$ & $69.47 \pm 1.2$ & 173.27 & -5.2 \\
\hline
\end{tabular}

(Mean $\pm S D, n=3$ )

\section{Table 4. Evaluation of lansoprazole tablets}

\begin{tabular}{llllll} 
Formulation & $\begin{array}{l}\text { Weight } \\
\text { variation }\end{array}$ & $\begin{array}{l}\text { Thickness } \\
(\mathrm{mm})\end{array}$ & $\begin{array}{l}\text { Hardness } \\
\left(\mathrm{kg} / \mathrm{cm}^{2}\right)\end{array}$ & $\begin{array}{l}\text { Friability } \\
(\%)\end{array}$ & $\begin{array}{l}\text { Assay } \\
(\%)\end{array}$ \\
\hline F1 & Complies & $3.18 \pm 0.14$ & $5.66 \pm 0.29$ & 0.886 & $99.93 \pm 1.16$ \\
\hline F2 & Complies & $3.23 \pm 0.11$ & $5.65 \pm 0.2$ & 0.752 & $99.47 \pm 1.81$ \\
\hline F3 & Complies & $3.09 \pm 0.17$ & $5.72 \pm 0.15$ & 0.892 & $98.18 \pm 1.43$ \\
\hline F4 & Complies & $3.21 \pm 0.09$ & $5.81 \pm 0.1$ & 0.836 & $99.97 \pm 1.97$ \\
\hline F5 & Complies & $3.27 \pm 0.21$ & $5.9 \pm 0.21$ & 0.811 & $99.01 \pm 2.13$ \\
\hline F6 & Complies & $3.15 \pm 0.12$ & $5.83 \pm 0.07$ & 0.798 & $98.43 \pm 1.73$ \\
\hline
\end{tabular}

\section{Particle shape and morphology (12)}

The shape and morphology of nanosponges was examined using Scanning Electron Microscopy (LEO 440I). Sample was deposited on a glass slide, and was kept under vacuum. The samples were coated with a thin gold/palladium layer using a sputter coater unit. The scanning electron microscope was operated at an acceleration voltage of $15 \mathrm{kV}$.

\section{Fourier transform infrared spectroscopy studies (12)}

The FTIR spectral measurements were taken at ambient temperature using a Perkin Elmer Model 1600 (USA). Samples were dispersed in $\mathrm{KBr}$ powder and the pellets were made by applying 5 ton pressure. FTIR spectra were obtained by powder diffuse reflectance on FTIR spectrophotometer.

\section{Differential scanning calorimetric studies (12)}

Differential scanning calorimetry (DSC-60, Shimadzu Corporation, Japan) studies were carried out to check compatibility between drug and polymers. DSC was used after calibration with Indium and lead standards, samples (3-5 $\mathrm{mg}$ ) were heated (range $50-400{ }^{\circ} \mathrm{C}, 10{ }^{\circ} \mathrm{C} / \mathrm{min}$ ) in crimped aluminium pans under a nitrogen atmosphere. The enthalpy of fusion and melting point were automatically calculated.

\section{Porosity}

Bulk volume was obtained by pouring the nanosponges in to a grated cylinder and is noted. It is then under gone for 100 tappings and the volume is noted as true volume.

$\%$ Porosity= (Bulk Volume-True Volume/Bulk volume $) \times 100$

\section{Determination of residual solvents concentration (13)}

Gas chromatography (Shimadzu GC-14B chromatograph, Japan) was used to estimate residual dichloromethane in lansoprazole nanosponges. Dichloromethane content in nanosponges was determined by gas chromatography on an Agilent 7890 Gas Chromatograph, USA fitted with a flame ionization detector. For estimation of residual solvents, $100 \mathrm{mg}$ of nanosponges were dissolved in little amount of DMSO in a $10 \mathrm{~mL}$ volumetric flask and volume was made up to $10 \mathrm{~mL}$ with DMSO. The solution was filtered through $0.45 \mu \mathrm{m}$ filter and degassed using sonicator. From the sample, $1 \mu \mathrm{l}$ was injected into injection port, the chromatogram was recorded and the peak area of solvent was measured. A calibration curve was plotted for dichloromethane in the range of $10-50 \mathrm{ppm}$. A good linear relationship was observed between the concentration of dichloromethane and its peak area $\left(r^{2}=0.9989\right)$. The concentration of residual solvent was calculated from calibration curve data.

\section{Preparation of lansoprazole tablets}

Lansoprazole tablets were prepared by direct compression method. The prescribed quantity of lansoprazole nanosponges, polymers and excipients (Table 2 ) were mixed homogeneously and the mixture was then compressed into tablets $(100 \mathrm{mg}$ ) using an $8 \mathrm{~mm}$, biconcave punches on a 'Rimek mini press 16 station rotary compression machine. 


\section{Evaluation of lansoprazole tablets}

\section{Weight variation}

The weight variation test was performed according to specifications given in the Indian Pharmacopoeia on 20 tablets. The maximum acceptable limit is $\pm 7.5 \%$ deviation of an individual weight from average weight.

\section{Thickness}

The thickness of 20 randomly selected tablets from each formulation was determined in $\mathrm{mm}$ using a vernier caliper (Pico India).

\section{Hardness}

Twenty tablets were randomly selected from each formulation and measured hardness in $\mathrm{kg} / \mathrm{cm}^{2}$ using Monsanto type hardness tester.

\section{Friability}

Tablet friability was measured using the Roche Friabilator. Randomly selected twenty pre-weighed tablets were placed in the apparatus and operated for 100 revolutions and then the tablets were reweighed. The friability was determined as the mass loss in percent according to following to Equation

\section{$F=(W A-W B / W A) \times 100$}

Where F: Friability, WA: Initial weight (gm), WB: Final weight (gm); the acceptable limits of the weight loss should not be more than $1 \%$.

\section{Assay}

Ten tablets were randomly selected from each formulation and crushed to a fine powder in mortar with pestle. Weigh accurately equivalent to $10 \mathrm{mg}$ of lansoprazole from fine powder then transfer in $100 \mathrm{~mL}$ volumetric flask, $100 \mathrm{~mL}$ of methanolic HCL was added to dissolve and sonicated for 20 minutes. Lansoprazole was extracted by centrifuging at $1000 \mathrm{rpm}$ for $30 \mathrm{~min}$. The samples were filtered, diluted and analyzed UV spectrophotometrically at $239 \mathrm{~nm}$.

\section{Enteric coating of lansoprazole tablets (14)}

Enteric coating of optimized lansoprazole tablets was done to protect the drug in acidic environment. Coating solution was prepared by dissolving $5 \% \mathrm{w} / \mathrm{v}$ of cellulose acetate phthalate and $1.5 \% \mathrm{w} / \mathrm{v}$ of propylene glycol 400 in acetone. Coating solution was applied by dip coating technique using pipette (10 $\mathrm{mL}$ ) attached to vacuum pump. Vacuum pump produced suction force that allowed tablet to adhere to pipette mouth. This adhered tablet was then partially dipped in coating solution to allow coat formation at one side of tablet. The other side was coated when other side dried.

\section{In vitro release studies $(15,16)$}

A calibration curve was plotted for lansoprazole in $\mathrm{pH} 1.2$ and $\mathrm{pH} 6.8$ buffers in the range of $3-18 \mu \mathrm{g} / \mathrm{mL}$ (Beer's Lambert's range) at $306 \mathrm{~nm}$ and $285 \mathrm{~nm}$ respectively. A good linear relationship was observed between the concentration of lansoprazole and its absorbance in $\mathrm{pH} 1.2$ buffer $\left(r^{2}=0.9987\right.$,

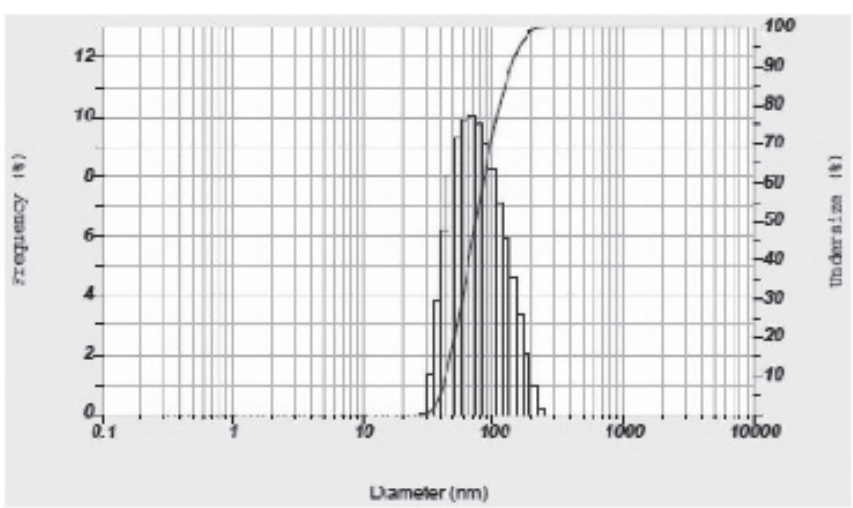

Figure 1. Particle size of lansoprazole nanosponges (F2)

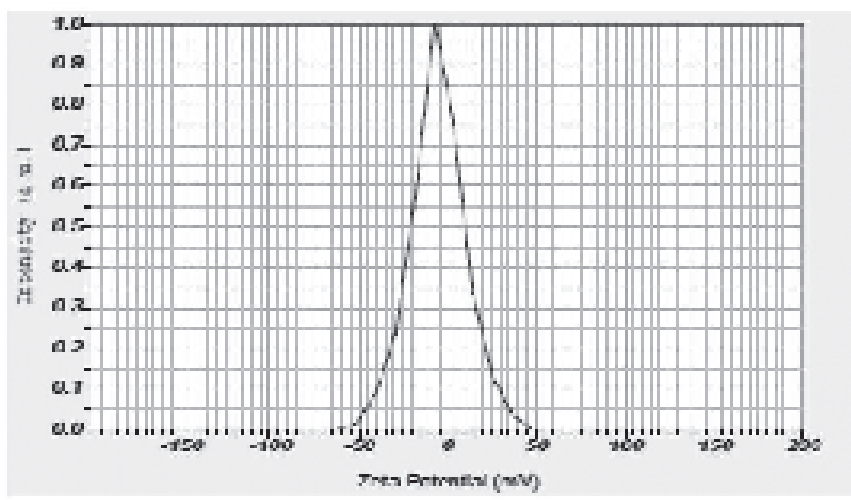

Figure 2. Zeta potential of lansoprazole nanosponges (F2)
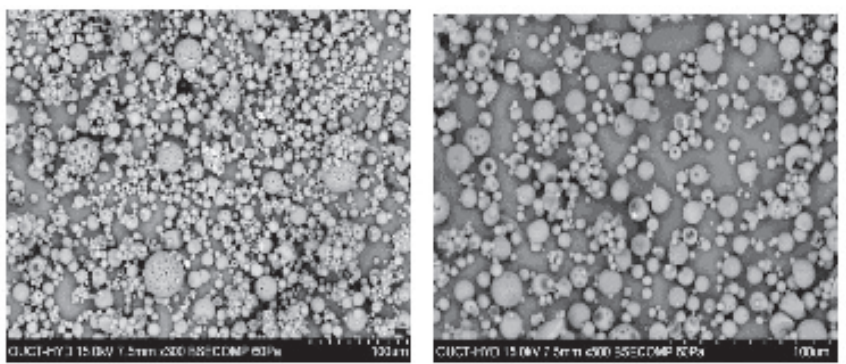

Figure 3. Scanning electron micrograph of lansoprazole nanosponges

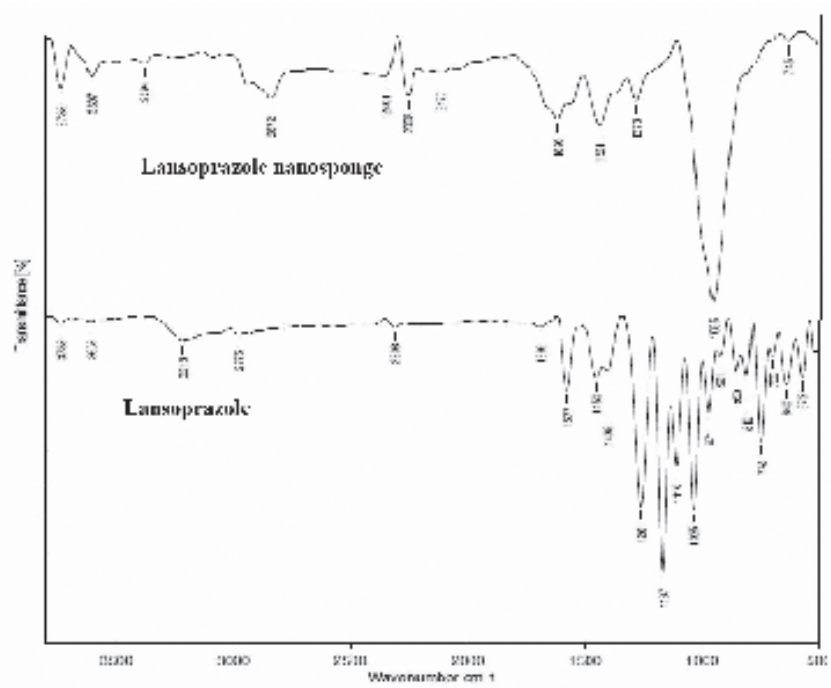

Figure 4. FTIR spectra of lansoprazole and lansoprazole nanosponges 
$m=0.0089, n=3)$ and $\mathrm{pH} 6.8$ buffer $\left(r^{2}=0.9979, m=0.0189, n=3\right)$. The dissolution test for optimized lansoprazole nanosponges and coated tablets was carried out according to USP $27 \mathrm{NF}$ 22 by adapting the method $\mathrm{B}$ in $\mathrm{pH} 1.2$ and $\mathrm{pH} 6.8$ buffers.

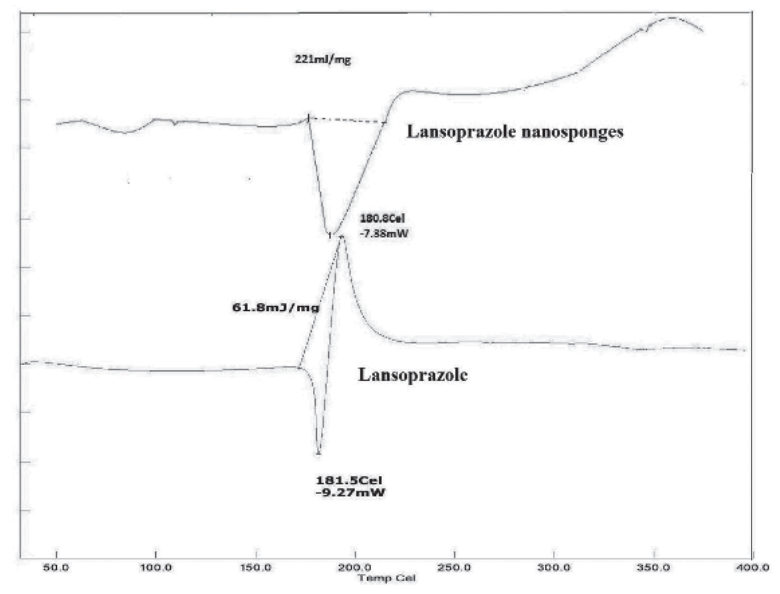

Figure 5. DSC thermograms of lansoprazole and lansoprazole nanosponges

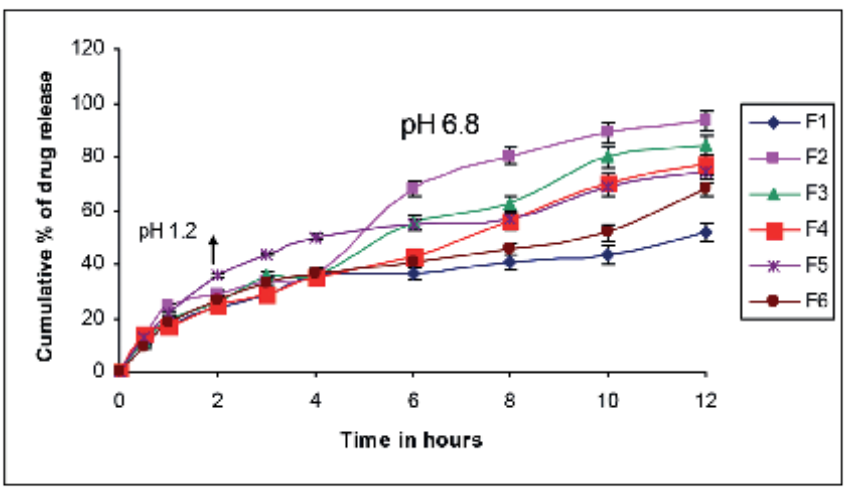

Figure 6. In vitro release profiles of lansoprazole nanosponges

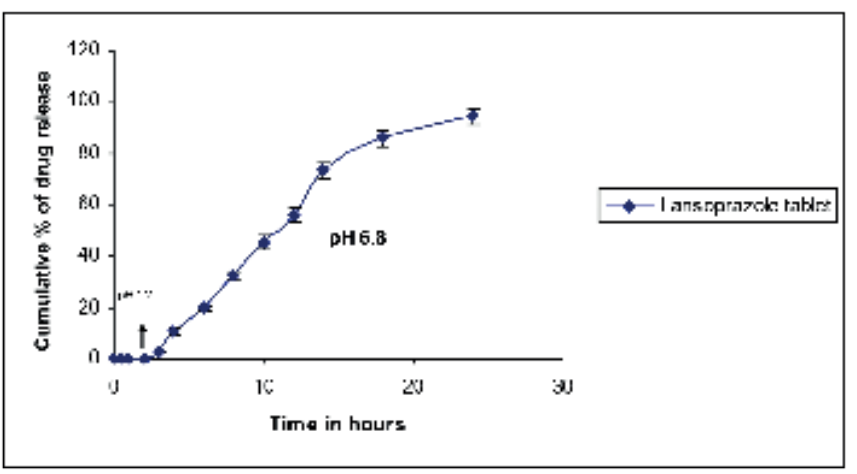

Figure 7. In vitro release profile of lansoprazole enteric coated tablet
Dissolution test was carried out using USP apparatus 1 (Model No TDT-08L, Electrolab, Mumbai) at $100 \mathrm{rpm}$. To reproduce digestive physiological phases, dissolution medium $(900 \mathrm{~mL}$ ) with different $\mathrm{pH}$ environments at $37 \pm 0.5^{\circ} \mathrm{C}$ was used. Six tablets were introduced into the apparatus and the apparatus was run for $2 \mathrm{~h}$ in $\mathrm{pH} 1.2$ buffer and $5 \mathrm{~mL}$ sample was withdrawn at various time intervals and the same volume of fresh dissolution medium was replaced to maintain sink condition. The samples were filtered, diluted and analyzed UV spectrophotometrically (Shimadzu, Japan) at $306 \mathrm{~nm}$. After $2 \mathrm{~h}$ the dissolution medium with the $\mathrm{pH}$ of 1.2 was replaced with 6.8 buffer and continued for up to $24 \mathrm{~h}$. Five millilitre samples were withdrawn at regular intervals and the same volume of fresh dissolution medium was replaced to maintain sink condition. The samples were filtered, diluted and analyzed UV spectrophotometrically at $285 \mathrm{~nm}$. Dissolution studies were performed and the mean cumulative percentage of lansoprazole was calculated and plotted against time.

\section{Evaluation of release kinetics (17-20)}

To investigate the mechanism of lansoprazole release from nanosponges and enteric coated tablets, the release data was analyzed for zero order, first order, Higuchi model and Korsmeyer-Peppas model. The data was presented in the following graphical representation and regression analysis was performed.

$M_{t}$ versus $t$ (zero order)

Log cumulative \% of drug remained versus $t$ (first order)

$M_{t}$ versus square root of $t$ (Higuchi)

Log $M_{t}$ versus log $t$ (Korsmeyer-Peppas)

$M_{t}$ is the cumulative \% of drug released/permeated at time t.

Korsmeyer et al (20) derived a simple relationship which described drug release from a polymeric system.

$M_{t} / M_{\infty}=k_{t}{ }^{n}$

Where, $M_{t} / M_{\infty}$ is the fraction of drug released at time $t, k$ is the rate constant and $\mathrm{n}$ is the release exponent. Release curve where $\mathrm{Mt} / \mathrm{M}_{\infty}<0.6$ was used to determine the exponent ' $n$ ' value. The $n$ value was used to characterize different release mechanisms. For example, $\mathrm{n}=0.45$ for Case $\mathrm{I}$ or Fickian diffusion, $0.45<\mathrm{n}<0.89$ for anomalous behaviour or non-Fickian transport, $\mathrm{n}=0.89$ for Case II transport, and $n$ $>0.89$ for Super Case II transport. Fickian diffusional release occurs by the usual molecular diffusion of the drug due to a chemical potential gradient. Case II relaxational release is the drug transport mechanism associated with stresses

Table 5. Comparison of correlation coefficient $\left(r^{2}\right)$ and rate constant of different kinetic models for F2 and enteric coated tablets

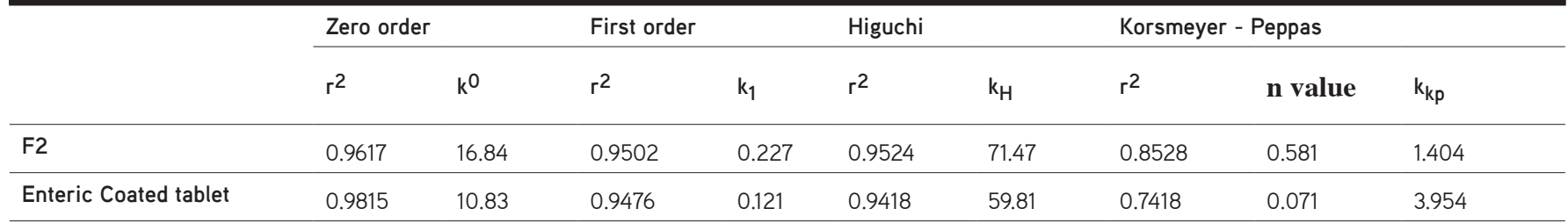


and state-transition in hydrophilic glassy polymers, which swell in water or biological fluids. This term also includes polymer disentanglement and erosion. The rate constant ' $k$ ', coefficients of correlation $\left(r^{2}\right)$ and ' $n$ ' of each model were calculated by linear regression analysis.

\section{RESULTS AND DISCUSSION}

Percentage yield value, drug entrapment efficiency, particle size and zeta potential of lansoprazole nanosponges were shown in Table 2.

Percentage yield value of nanosponges was found to be best for F2. Further increasing the concentration of polymer the $\%$ yield was found to be decreased due to the sticky nature of the product which can not be filtered. The entrapment efficiency of nanosponges was found to be best for formulation F2. Further increasing the concentration of the polymer, entrapment efficiency was found to be decreased due to low solubility of polymer in aqueous phase $(22,23)$. The size of the nanosponges was found to be in the range $83.4 \mathrm{~nm}$ to $190.69 \mathrm{~nm}$ (Table 3 and Figure 1). The zeta potential of the nanosponges was found to be in the range $-4.9 \mathrm{mV}$ to $-5.6 \mathrm{mV}$ (Table 3 and Figure 2). The negative sign indicates the stability of nanosponges.

The SEM images of the lansoprazole nanosponges were shown in Figure 3. SEM analysis revealed that Nanosized spherical particles with numerous pores on surface (lansoprazole nanosponges). The pores are tunneled inwards which may be due to diffusion of dichloromethane from the surface of the nanosponges (5).

The FTIR spectra of pure lansoprazole and lansoprazole nanosponges are shown in Figure 4. FTIR spectra of pure lansoprazole demonstrated the characteristic absorption peaks of $3608 \mathrm{~cm}$ for $\mathrm{N}-\mathrm{H}$ stretching, at $2976 \mathrm{~cm}$ for aromatic $\mathrm{C}-\mathrm{H}$ stretching, $2308 \mathrm{~cm}$ for aromatic C-N stretching, $1577 \mathrm{~cm}$ for $\mathrm{C}=\mathrm{C}$ stretching and 1261 for $\mathrm{S}=\mathrm{O}$ stretching. Lansoprazole nanosponges also showed almost similar absorption peaks indicates good compatibility with polymers (12).

DSC thermogram of pure lansoprazole shows sharp peak at $181.5^{\circ} \mathrm{C}$ corresponding to its melting point (Figure 5). Lansoprazole nanosponge showed a similar endothermic peak at $180.8^{\circ} \mathrm{C}$ which confirms no polymer drug interaction (12).

Porosity study is performed to check the extent of nanochannels and nanocavities formed. Porosity of the nanosponges can also be assessed by the use of density of nanosponges. Owing to their porous nature, nanosponges exhibit higher porosity compared to the parent polymer used to fabricate the system. Porosity of the nanosponges was found to be $60 \%$ and the bulk volume of the nanosponges was found to be $80 \mathrm{~mL}$ and true volume was found to be $32 \mathrm{~mL}$.

The concentration of dichloromethane was found to be 298 ppm. According to Guidelines for residual solvents Q3C (ICH), dichloromethane is class II solvent (solvents to be limited) thus the limits of 600 ppm is acceptable without justification.
Lansoprazole tablets were evaluated for weight variation, thickness, hardness, friability and assay. The results of the evaluation are given in Table 4.

In vitro release studies of lansoprazole nanosponges were carried out in triplicate. After $12 \mathrm{~h}$ the release was found to be $51.94 \pm 3.26,93.47 \pm 3.51,84.38 \pm 3.53,76.92 \pm 3.73,74.26 \pm 2.96$ and $67.73 \pm 2.49 \%$ for the formulations F1, F2, F3, F4, F5 and F6 respectively (Figure 6).

To study the release kinetics of optimized formulation, obtained in vitro release data was fitted in various kinetic models such as zero order, first order, Higuchi model and Korsmeyer-Peppas model. The in vitro release profile of F2 could be best expressed by zero order kinetic model, as the plot showed highest linearity $\left(r^{2}=0.961\right)$. The release exponent (n) value 0.581 (Table 5) indicates that the release from nanosponges followed non fickian release i.e., by swelling and erosion which is always associated with diffusion and dissolution mechanism.

Based on entrapment efficiency and \% drug release profiles F2 was selected as optimized formulation and it was formulated in to tablet by direct compression and coated by dipping the tablets in coating solution $(5 \% \mathrm{w} / \mathrm{v}$ cellulose acetate phthalate and $1.5 \% \mathrm{w} / \mathrm{v}$ polyethylene glycol 400 in acetone). After $10 \mathrm{~min}$ the tablets were removed and air dried.

The enteric coated tablets were subjected to weight variation, hardness, friability, thickness and in vitro dissolution studies. The average weight of all tablets was found to be $101.27 \pm 2.78$. The deviation of all tablets was found to be within the limit. So, all formulations passed the test for uniformity of weight as per official requirements. Thickness of the tablets was found to be $3.37 \pm 0.21 \mathrm{~mm}$. Hardness of tablets was found to be $5.7 \pm 0.10 \mathrm{~kg} / \mathrm{cm}^{2}$. Percentage friability of tablets was found to be 0.89 i.e., less than $1 \%$, indicating that the friability was within the prescribed limits. All the tablets showed acceptable properties and complied with the I.P specifications for weight variation, hardness, and friability.

Lansoprazole enteric coated tablet showed no release of drug in acidic medium which is desirable and $94.24 \pm 3.02 \%$ at the end of $24 \mathrm{~h}$ (Figure 7). The in vitro release profile of lansoprazole enteric coated tablets could be best expressed by zero order kinetic model, as the plot showed highest linearity $\left(r^{2}=0.981\right)$. The release exponent $(n)$ value 0.071 (Table 5 ) indicates that the release from coated tablets followed fickian release i.e., release always associated with diffusion mechanism (20).

\section{CONCLUSION}

The nanosponges containing lansoprazole exhibited most of the ideal characters required for an oral controlled release dosage forms. The nanosponges of lower particle size $83.4 \mathrm{~nm}$ aided with negatively charged surface charge has been achieved. The release profile indicated continuous controlled release up to $12 \mathrm{~h}$. Lansoprazole enteric coated tablet showed no release 
of drug in acidic medium which is desirable and controlled release behavior for a period of $24 \mathrm{~h}$. The nanosponge systems have been found to have good potential for prolonged drug release and therefore can be beneficial such as dose reduction, reduced frequency of administration and avoiding related systemic side effects. Hence it can be concluded that the developed oral enteric coated tablet - nanosponges of lansoprazole is considered to be ideal and effective in the management of ulcer and related conditions.

\section{ACKNOWLEDGEMENTS}

The authors are thankful to Dr. Reddy's Labs, Hyderabad, India for the gift sample of lansoprazole. We also thank the MNR educational trust and Sri Padmavathi Mahila Visva Vidyalayam for providing necessary facilities to carrying the work.

\section{REFERENCES}

1. Vyas SP, Khar RK. Novel Carrier Systems. Molecular Basis of Targeted Drug Delivery. In: Targeted and Controlled Drug Delivery, pp. 38-40, CBS Publishers and Distributors, New Delhi, 2008.

2. Jilsha G, Vidya Viswanad. Nanosponges: A Novel Approach of Drug Delivery System. Int J Pharm Sci Rev Res 19(2), 119-123, 2013.

3. Lala R, Thorat A, Gargote C. Current trends in $\beta$ - cyclodextrin based drug delivery systems. Int J Res Ayur Pharm 2(5), 1520-1526, 2011.

4. Jenny A, Merima P, Alberto F, Francesco T. Role of $\beta$-cyclodextrin nanosponges in propylene photooxidation. Carbohydrate Polymers. 86(1), 127-135, 2011.

5. Renuka Sharma, Roderick BW, Kamla Pathak. Evaluation of kinetics and mechanism of drug release from econazole nitrate nanosponge loaded carbapol hydrogel. Ind J Pham Edu Res 45(1), 25-31, 2011.

6. Matheson AJ and Jarvis B. Lansoprazole: an update of its place in the management of acid-related disorder. Drugs 61(2), 1801-1833, 2001.

7. Nagarajan E, Shanmugasundaram P, Ravichandirana V, Vijayalakshmi A, Senthilnathan B, Masilamani K, Development and evaluation of chitosan based polymeric nanoparticles of an antiulcer drug lansoprazole. J App Pharm Sci 5(4), 20-25, 2015.

8. Shimizu T, Nakano Y, Morimoto S, Tabata T, Hamaguchi N, Igari Y. Formulation study for Lansoprazole fast-disintegrating tablet. I. Effect of compression on dissolution behavior. Chem Pharm Bull 51(8), 942947, 2003.

9. Venkateswarlu P. Formulation and In Vitro Evaluation of Lansoprazole Delayed Release Capsules Int J Innov Pharm Sci Res 4(3), 328-336, 2013.

10. Cavalli R, Trotta F, Tumiatti W. Cyclodextrin-based Nanosponges for Drug Delivery. J Incl Phenom Macrocycl Chem 56(1-2), 209-213, 2006.
11. Swaminathan S, Linda P, Loredana S, Francesco T, Pradeep V, Dino A, Michele T, Gianpaolo Z, Roberta C. Cyclodextrin-based nanosponges encapsulating camptothecin: Physicochemical characterization stability and cytotoxicity. Eur J Pharm Biopharm 74(2), 193-201, 2010.

12. Swaminathan S, Pradeep V, Trotta F, Cavalli R. Nanosponges encapsulating dexamethasone for ocular delivery: formulation design, physicochemical characterization, safety and corneal permeability. J Biomed Nanotechnol 9(6), 998-1007, 2013.

13. Prasanna Reddy Battu, Reddy MS. Residual solvents determination by HS-GC with flame ionization detector in omeprazole pharmaceutical formulations. Int J PharmTech Res 1(2), 230-234, 2009.

14. Bajpai $M$, Singh DCP, Bhattacharya $A$, Singh $A$. Design and in vitro evaluation of compression-coated pulsatile release tablets of losartan Potassium. Ind J Pharm Sci 74(2), 101-106, 2012.

15. Kalantzi LE, Karavas E, Koutris EX, Bikiaris DN. Recent advances in oral pulsatile drug delivery. Recent Pat Drug Deliv Formul 3(1), 49-63, 2009.

16. Paulo C, Jose M. Modeling and comparision of dissolution profiles, Eur J Pharm Sci 13(2), 123-133, 2001.

17. Higuchi T. Mechanism of sustained action medication: theoretical analysis of rate of release of solid drugs dispersed in solid matrices. $J$ Pharm Sci 52, 1145-1148, 1963.

18. Brazel CS, Peppas NA. Modeling of drug release from swellable polymers, Eur J Pharm Biopharm 49(1), 47-58, 2000.

19. Lapidus $H$, Lordi NG. Some factors affecting the release of a watersoluble drug from a compressed hydrophilic matrix. J Pharm Sci 55(8), 840-843, 1966.

20. Korsmeyer RW, Gurny R, Doelker E, Buri P, Peppas NA. Mechanisms of solute release from porous hydrophilic polymers. Int J Pharm 15(1), 25-35, 1983

21. Peppas NA. Analysis of Fickian and non- Fickian drug release from polymers. Pharm Acta Helv 60(4), 110-111, 1985.

22. Raja CHNV, Kiran Kumar G, Kotapati Anusha. Fabrication and Evaluation of Ciprofloxacin Loaded Nanosponges for Sustained Release. International Journal of Research In Pharmaceutical And Nano Sciences 2(1), 1-9, 2013.

23. Ansari KA, Torne SJ, Pradeep RV, Trotta F, Cavalli R. Paclitaxel loaded nanosponges: in-vitro characterization and cytotoxicity study on MCF7 cell line culture. Curr Drug Deliv 8(2), 194-202, 2011.

Received : 18.01.2016

Accepted : 03.04.2016 